\title{
Purity, Holiness, and Identity in Judaism and Christianity
}

\author{
Essays in Memory of Susan Haber \\ Ed. by Carl S. Ehrlich, Anders Runesson and Eileen Schuller
}

[Reinheit, Heiligkeit und Identität in Judentum und Christentum. Aufsätze in Erinnerung an Susan Haber.]

Purity, Holiness, and Identity in Judaism and Christianity

\section{Edited by} CARL S. EHRLICH, ANDERS RUNESSON an EILEEN SCHULLER

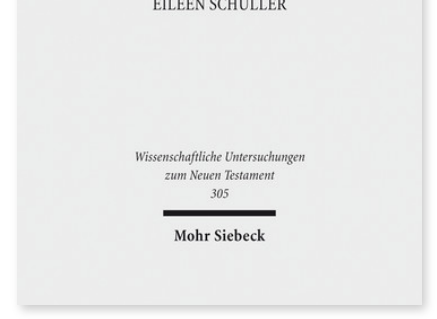

2013. X, 313 Seiten. WUNT I 305

ISBN 978-3-16-152548-3

DOI 10.1628/978-3-16-152548-3

eBook PDF 149,00€

ISBN 978-3-16-152547-6

Leinen $149,00 €$
Veröffentlicht auf Englisch.

Susan Haber (1957-2006) war Absolventin der York University (Toronto/Kanada) und der McMaster University (Hamilton/Kanada). Sie arbeitete an ihrer Dissertation an der McMaster University und hatte schon verschiedene Aufsätze zur hebräischen Bibel, dem frühen Judentum und dem frühen Christentum veröffentlicht, als sie verstarb. Der vorliegende Band besteht aus Beiträgen von ihren Lehrern, Freunden und Kollegen. Die Aufsätze behandeln Themen von zentraler Bedeutung für das theologische Verständnis des Judentums und des Christentums: Reinheit, Heiligkeit, und Identität. Obwohl es in den einzelnen Aufsätzen nicht immer explizit ausgedrückt wird, bietet ihr Nebeneinander eine Grundlage für den interreligiösen Dialog.

Mit Beiträgen von:

Ehud Ben Zvi, Yedida Eisenstadt, Eric Grossman, Philip Harland, Thomas Kazen, Martin I. Lockshin, Steve Mason, Adele Reinhartz, Anders Runesson, Eileen Schuller, Baruch J. Schwartz, David Seed, Lily Vuong, Cecilia Wassen, Stephen Westerholm

Inhaltsübersicht

Preface David Seed: Susan Haber: A Brief Biography and Appreciation Part I: Ancient Israel Baruch J. Schwartz: MIQRA' QODEŠ and the Structure of Leviticus 23 - Eric Grossman: Everyman's Judgment Cometh From The LORD: Popular Perception of the Primary Purpose of the Cult - Ehud Ben Zvi: Purity Matters in the Book of Chronicles: A Kind of Prolegomenon Part II: Classical Antiquity Cecilia Wassen: Do You Have to Be Pure in a Metaphorical Temple? Sanctuary Metaphors and Construction of Sacred Space in the Dead Sea Scrolls and Paul's Letters - Stephen Westerholm: Is Nothing Sacred? Holiness in the Writings of Paul - Adele Reinhartz: The Temple Cleansing and the Death of Jesus - Thomas Kazen: Jesus and the Zavah: Implications for Interpreting Mark - Anders Runesson: Purity, Holiness, and the Kingdom of Heaven in Matthew's Narrative World - Steve Mason: Pollution and Purification in Josephus's Judean War - Philip Harland: »The days seemed like years«: Thessalos Prepares to Encounter the God Asklepios - Lily Vuong: The Impact of Social and Economic Status on the Experience of Martyrdom: A Case Study of Perpetua and Felicitas Part III: The Mediaeval and Modern Periods Martin I. Lockshin: Is Holiness Contagious? - Yedida Eisenstadt: Sanctification and Shame: Bialik's In the City of Slaughter in Light of Leviticus and Ezekiel - Eileen Schuller: Biblical Texts about Purity in Contemporary Christian Lectionaries

Carl S. Ehrlich Born 1956; 1991 PhD, Harvard University; since 1996 Professor of Hebrew Bible in the Department of Humanities at York University, Canada.

Anders Runesson Born 1968; 2001 PhD; 2002 Docent, Lund University, Sweden; 2003-15 Professor of Early Christianity and Early Judaism, McMaster University, Canada; since 2015 Professor of New Testament in the Faculty of Theology at the University of Oslo, Norway.

https://orcid.org/0000-0001-6042-0101

Eileen Schuller Born 1946; 1984 PhD, Harvard University; since 1990 Professor of Early Judaism in the Department of Religious Studies, McMaster University, Canada.

Jetzt bestellen:

https://mohrsiebeck.com/buch/purity-holiness-and-identity-in-judaism-and-christianity-9783161525483?no_cache=1 order@mohrsiebeck.com

Telefon: +49 (0)7071-923-17

Telefax: $+49(0) 7071-51104$ 